\title{
Assistive technology applied to education of students with visual impairment
}

\author{
Cássia Cristiane de Freitas Alves, ${ }^{1}$ Gelse Beatriz Martins Monteiro, ${ }^{1}$ \\ Suzana Rabello, ${ }^{1}$ Maria Elisabete Rodrigues Freire Gasparetto, ${ }^{1}$ \\ and Keila Monteiro de Carvalho ${ }^{1}$
}

Suggested citation

Alves CCF, Monteiro GBM, Rabello S, Gasparetto MERF, Carvalho KM. Assistive technology applied to education of students with visual impairment. Rev Panam Salud Publica. 2009;26(2):148-52.

ABSTRACT Objectives. Verify the application of assistive technology, especially information technology in the education of blind and low-vision students from the perceptions of their teachers. Methods. Descriptive survey study in public schools in three municipalities of the state of São Paulo, Brazil. The sample comprised 134 teachers.

Results. According to the teachers' opinions, there are differences in the specificities and applicability of assistive technology for blind and low-vision students, for whom specific computer programs are important. Information technology enhances reading and writing skills, as well as communication with the world on an equal basis, thereby improving quality of life and facilitating the learning process. The main reason for not using information technology is the lack of planning courses. The main requirements for the use of information technology in schools are enough computers for all students, advisers to help teachers, and pedagogical support.

Conclusions. Assistive technology is applied to education of students with visual impairment; however, teachers indicate the need for infrastructure and pedagogical support. Information technology is an important tool in the inclusion process and can promote independence and autonomy of students with visual impairment.

Key words Assistive technology; visually impaired persons; information technology; Brazil.

Assistive technology is an interdisciplinary field of knowledge comprising products, resources, methodologies, strategies, practices, and services that aims to promote functionality for visually impaired people with regard to autonomy, independence, quality of life, and social inclusion (1).

\footnotetext{
Faculty of Medical Sciences, University of Campinas, Campinas, Brazil. Send correspondence and reprint requests to: Cássia Cristiane de Freitas Alves, Department of Ophthalmology, Faculty of Medical Sciences, University of Campinas, P.O. Box 6111, Rua Tessalia Vieira de Camargo, 126, Campinas, São Paulo 13084-970, Brazil; telephone: 551135217380; fax: 551135217380; e-mail: cassia. freitas@hotmail.com
}

Information technology, the main assistive technology resource applied to educating visually impaired students, can be defined as computers with programs that allow students to access the digital environment, promoting individual life and social/education inclusion. ${ }^{2}$

Inclusive schools provide all students with a regular classroom, thus ensuring adequate and challenging educational opportunities fitted to their abilities and

\footnotetext{
Alves, CCF. The use of computer science resources in the education of visually impaired students: teacher's knowledge, opinions and practices [dissertation]. Campinas, São Paulo: University of Campinas; 2007.
}

needs, according to the principle of educational inclusion defined in the Salamanca Declaration $(2,3)$.

Visual impairment is divided into two groups with distinct characteristics and needs: individuals with low vision and individuals with blindness.

Low-vision individuals have impaired visual function even after optical correction and use or are able to use their vision to perform tasks. In the educational field, students with low vision have residual vision, which enables them to read printed material with the aid of didactic resources and special equipment $(4,5)$. 
Blindness is the term used to describe total loss of vision and conditions in which individuals need to rely predominantly on vision substitution skills. In the educational field, a blind student does not use vision in the learning process $(4,5)$.

The loss of visual ability causes unfavorable consequences at both the individual and collective levels. Blindness generates psychological, social, and economic problems as well as problems concerning quality of life, since it may lead to loss of self-esteem and autonomy (6).

Students with low vision may have difficulties with reading and writing activities, even when they use optical aids (that magnify the image) and nonoptical resources (material adaptation and changes in the environment) (7). Those students can benefit from the combined use of these resources with information technology, such as screen enlargers (systems that magnify the characters on a computer) and speech synthesizers (specific adaptations with voice output, which convert screen content to speech).

Information technology allows individuals with visual impairment to overcome a major part of the difficulties in daily life and offers them independence and autonomy concerning information management and access to communication, just like their peers with normal vision (8).

Many voice synthesizers and screen readers are available for purchase from companies or nongovernmental organizations or are available for free use on the Internet. These programs allow access to Internet websites.

Assistive technology resources are increasingly becoming a concrete means of access to information, communication, and social inclusion (9).

Including visually impaired students in schools requires special attention. The teacher should be able to competently manage assistive technology resources, which can be considered a condition for an efficient pedagogical relationship (10).

To ensure educational and social inclusion of students with visual impairment, ophthalmology has prioritized research that focuses on the patient's global treatment, including physicians, pedagogues, and rehabilitation professionals. Therefore, it is important to know the environment where teachers of students with visual impairment work in order to help them perform appropriately.

The objective of this research was to verify the application of assistive technol- ogy, especially information technology, in educating blind and low-vision students from the perceptions of their teachers.

\section{MATERIALS AND METHODS}

A descriptive survey study was carried out in public schools in three municipalities in the state of São Paulo, Brazil. The sample consisted of 58 teachers who taught students with visual impairment and 76 teachers who did not teach these students, even though they worked in schools that visually impaired students attended. The sample was selected according to the following criteria: (1) to work in schools attended by students with visual impairment and (2) to teach at the elementary, middle, or high school level in public schools.

A self-applicable questionnaire was developed that contained questions for all teachers as well as questions directed to teachers who worked with visually impaired students. Along with the questionnaire, the patients filled out and signed a consent form for participation in the research. The study was approved by the Research Ethics Committee of the Faculty of Medical Sciences-Unicamp.

Data were collected between March and July 2006. The following variables were analyzed:

- Differences in the specificities and applicability of assistive technology resources to the needs of blind and low-vision students

- Importance of schools having specific programs for students with visual impairment

- Importance ascribed to assistive technology in teaching students with visual impairment

- Use of information technology by students with visual impairment

- Necessary requirements for the use of information technology

A database was created using the program EPI-INFO, version 6.04d (11). The program SAS was used for statistical analysis (12). Frequency charts were used for categorical variables, and descriptive statistics (averages) were used for continuous variables.

\section{RESULTS}

Most teachers $(61.4 \%)$ stated that the use of assistive technology resources has different applicability for blind and lowvision students. They also declared that specific programs for students with visual impairment are necessary in schools $(98.3 \%)$ (Table 1).

Concerning the importance of using assistive technology resources in educating students with visual impairment, $84.2 \%$ of the teachers declared that the resources were very important to enhance reading and writing skills as well as to communicate with the world on an equal basis (95.8\%). In addition, they made information available and the content of the teaching material more attractive than the traditional resources $(93.7 \%)$, improving the students' quality of life, facilitating the learning process $(91.7 \%)$, and allowing them to rewrite and correct texts $(87.5 \%)$ with autonomy and privacy $(66.7 \%)$ (Table 1$)$.

The results showed that most teachers (94.8\%) did not use information technology with visually impaired students. The reasons were not having previously included in the course program the use of information technology in class $(70.4 \%)$, the lack of specific programs for students with visual impairment $(51.8 \%)$, the fact that the school administration did not make information technology available for teachers and students $(24.1 \%)$, the fact that students with visual impairment did not know how to use the computer, and the belief that the disability did not allow the individual to use the computer (20.4\%) (Table 2).

Regarding the necessary requirements for using information technology in schools, the teachers indicated the need for enough computers for all students in the class $(89.5 \%)$, a computer technology advisor to help teachers $(75.4 \%)$, pedagogical support to use information technology as a learning strategy $(74.6 \%)$, enough ability to use computers $(69.4 \%)$, programs for students with visual impairment $(68.7 \%)$, and Internet-connected computers $(59.7 \%)$ (Table 3$)$.

\section{DISCUSSION}

Teachers play a fundamental role in the task of promoting students' well being and in creating conditions for learning. They can also contribute to students' health by guiding them in the use of resources that enhance their residual vision and preserve their visual function (13).

Access to assistive technology provides independence to students with vi- 
Despite all these considerations, $94.8 \%$ of the teachers stated they did not use information technology (Table 3). There are many barriers to the use of information technology in schools, such as uneven allocation of equipment and poor access to computer resources. Students with special needs and underprivileged social groups lack access to information technology. ${ }^{3}$ It is important to create opportunities that maximize the students' potential, especially students with special needs.

The process of introducing information technology in schools requires that all teachers invest in the development of their abilities, so that their educational

\footnotetext{
3 Tanaka EH. Tornando um software acessível às pessoas com necessidades educacionais especiais [dissertation]. Campinas, São Paulo: Universidade Estadual de Campinas; 2001.
}

activities can benefit from technology tools. The success of using information technology for educational purposes depends on a collaborative effort between the school and the teachers, requiring planning that considers the needs and conditions of the school so that issues such as equipment maintenance and material supplies do not become an obstacle (18).

Committed to and involved with spreading information that eases the lives of students with low vision or blindness, the Department of Ophthalmology of the Faculty of Medical Sciences (Unicamp) developed a websitewww.auxiliosopticos.fcm.unicamp.brthat offers information and guidance to improve the work of teachers and students with visual impairment.

The use of assistive technology contributes to the use of residual vision and to the preservation of visual function. It is an important tool in the inclusion process. It allows health and education professionals to develop combined actions and to promote knowledge sharing and quality of life for visually impaired students (19).

Assistive technology is applied to education of students with visual impairment; however, teachers indicate the need for infrastructure and pedagogical support.

The study was limited to three municipalities in the state of São Paulo, Brazil, due to a shortage of financial and human resources and difficulty obtaining grants from government agencies.

We recommend a working partnership among school, family, and ophthalmic medical service, so that there is awareness of the limitations to be overcome and planning of actions that allow the use of assistive technology in educating visually impaired students.

\section{REFERENCES}

1. Cook A, Hussey SM. Assistive technologies: principles and practice. 2nd ed. St. Louis: Mosby; 2002.

2. World Conference on Special Needs Education: Access and Quality. The Salamanca Statement and Framework for Action on Special Needs Education. Salamanca, Spain: United Nations Education, Scientific and Cultural Organization and Ministry of Education and Science Spain; 1994.

3. Stainback $S$, Stainback W. Inclusion: a guide for educators. Baltimore, MD: Paul H. Brookes; 1996.

4. International Council of Ophthalmology. Visual standards: aspects and ranges of vision loss with emphasis on population surveys. 29th International Congress of Ophthalmology, 2 April 2002, Sidney, Australia. San Francisco: ICO; 2002. Available from: http:// www.icoph.org/standards/visionres.html\# adopt. Accessed 5 November 2007.

5. World Health Organization. Consultation on development of standards for characterization of visual loss and visual functioning. WHO/PBL/03.91. Geneva: WHO; 2003.

6. Kara-José N, Temporini ER. Cirurgia de catarata: o porquê dos excluídos. Rev Panam Salud Publica. 1999;6(4):242-48.

7. Carvalho KM, Monteiro GBM, Rodrigues IC, Shiroma LO, Amaral MS. Causes of low vision and use of optical aids in the elderly. Rev Hosp Clin Fac Med Sao Paulo. 2004;59(4): 157-60. Available from: http://www.scielo.
br/scielo.php?script=sci_arttext\&pid=S004187812004000400001\&lng=en. Accessed 12 December 2008.

8. Caparrós JAE. Tiflotecnología. In: Martír MB, Bueno ST, eds. Deficiencia visual: aspectos psicoevolutivos y educativos. Málaga: Ediciones Aljibe, SL; 1994.

9. Brasil, Ministério da Ciência e Tecnologia. Tecnologias assistivas e a promoção da inclusão social. Brasília: Ministério da Ciência e Tecnologia; 2005.

10. Baumel RCRC, Castro AM. Materiais e recursos de ensino para deficientes visuais. In: Baumel RCRC, ed. Educação especial: do querer ao fazer. São Paulo: Avercamp; 2003.

11. Dean AG, Dean JA, Coulombier P, Brendel KA, Smith DC, Burton AH, et al. Epi-info: a word processing, database, and statistics program for epidemiology on microcomputers. Version 6.04. Atlanta: Centers for Disease Control and Prevention; 2001.

12. The SAS System for Windows (Statistical Analysis System). Release 8.2 (TS2MO) Windows. Cary, NC: SAS Institute Inc.; 2004. Available from: http://support.sas.com/resources/ sysreq/82/win82m0.pdf. Accessed 10 April 2008.

13. Temporini ER, Carvalho RS, Kara-José N, Oliveira DF. A importância dos professores e da escola. In: Kara-José N, Gonçalves ER, Carvalho RS, eds. Olho no olho: Campanha Nacional de Prevenção à Cegueira e Reabilitação Visual do Escolar. São Paulo: CBO; 2006.
14. Galvão Filho TA. As novas tecnologias na escola e no mundo atual: fator de inclusão social do aluno com necessidades especiais? In: Anais eletrônicos do III Congresso Iberoamericano de Informática na Educação Especial. Fortaleza; 2002.

15. Freire FMP, Prado MEBB. O computador em sala de aula: articulando saberes. Campinas: Unicamp/Nied; 2000.

16. Thylefors B, Negrel AD, Pararajasegaram R, Dadzie KY. Global data on blindness. Bull World Health Organ. 1995;73(1):115-21.

17. Gasparetto MERF, Temporini ER, Carvalho KM, Kara-José N. O aluno portador de visão subnormal na escola regular: desafio para o professor? Arq Bras Oftalmol. 2001;64(1):45-51.

18. Freire FMP, Prado MEBB, Martins MC, Sidericoudes O. A implantação da informática no espaço escolar: questões emergentes ao longo do processo. Rev Bras Inform Educ. 1998;3: 45-62.

19. Carvalho RS, Kara-José N. Saúde e educação: considerações finais. In: Kara-José N, Gonçalves ER, Carvalho RS, eds. Olho no olho: Campanha Nacional de Prevenção à Cegueira e Reabilitação Visual do Escolar. São Paulo: CBO; 2006. Pp. 131-32.

Manuscript received on 18 August 2008. Revised version accepted for publication on 15 December 2008. 
RESUMEN Objetivos. Verificar el uso de tecnologías de asistencia, en particular tecnologías informáticas, en la educación de estudiantes ciegos y débiles visuales, desde la percepción de sus maestros. Uso de tecnologías
de asistencia en la educación de estudiantes con deficiencia visual

Palabras clave
Métodos. Estudio descriptivo mediante encuesta a 134 maestros de escuelas públicas de tres municipios del estado de São Paulo, Brasil.

Resultados. Según la opinión de los maestros hay diferencias en las especificidades y aplicabilidad de las tecnologías de asistencia para estudiantes ciegos y débiles visuales, para los que son importantes programas específicos de computación. Las tecnologías informáticas desarrollan las habilidades de lectura y escritura, así como la comunicación con el mundo sobre una base de igualdad, lo que mejora la calidad de vida y facilita el proceso de aprendizaje. La principal razón para no utilizar tecnologías informáticas es la falta de cursos de planificación. Los principales requisitos para usar tecnologías informáticas en las escuelas es tener suficientes computadoras para todos los estudiantes, asesores que ayuden a los maestros y apoyo pedagógico.

Conclusiones. Las tecnologías de asistencia se utilizan en la educación de estudiantes con deficiencia visual; no obstante, los maestros señalan la necesidad de infraestructura y apoyo pedagógico. Las tecnologías informáticas constituyen una herramienta importante para el proceso de inclusión y pueden propiciar la independencia y la autonomía de los estudiantes con deficiencia visual.

Dispositivos de autoayuda; personas con daño visual; tecnología de la información; Brasil. 